\title{
弡熱ト Katalase
}

椆山醫科大學柿沼丙科票室

$\begin{array}{ccccc}\text { 㗨士 } & \text { 日 } & \text { 下 } & & \text { 連 } \\ \text { 醫士 } & \text { 原 } & \text { 田 } & \text { 要 } & \text { 一 } \\ \text { 㗨學士 } & \text { 三 } & \text { 谷 } & & \text { 登 }\end{array}$

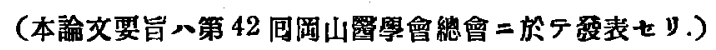

第 1 章 緒 論

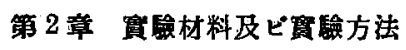

第 3 章 賽驗成嘖

第 1 節酸熱卜血液 Katalase

第 1 項 跑照試驗

第 2 項薙時貿驗
目灾

第2節 熱卜㓐器 Katalase

第 1 項 對照試騱

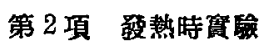

第 4 章 繶括及ビ考察

第 5 章 結 論

文

\section{第 1 章 緒 論}

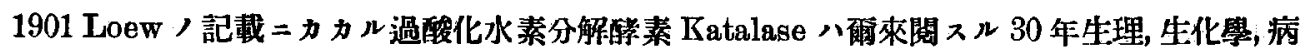

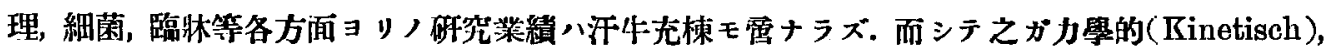

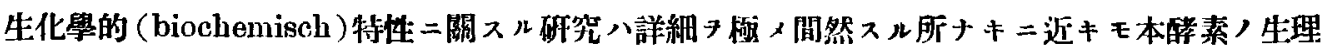

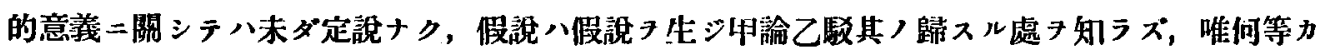

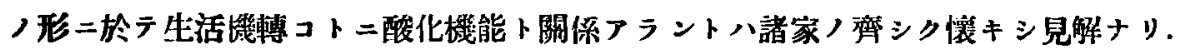

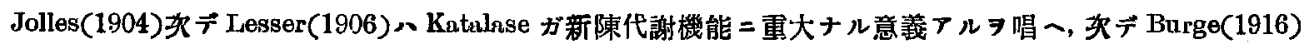
八酸化 (Oxydation) 卜自家融解 (Autolyse) /拮抗作用 $コ$ Autolyse 、 Kutuluse 堿少ニョルトノ見解

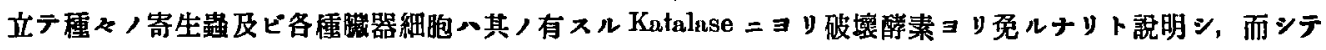

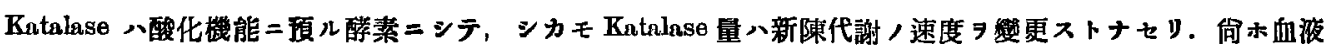

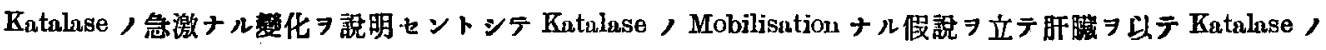

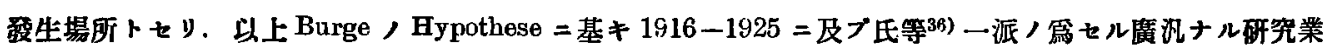

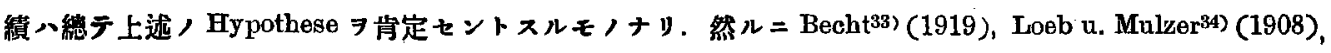
Stehle27) (1919) Winternitz u. Pratt ${ }^{35)}$, Reimann \& Bloom ${ }^{37}$, Reimnnn \& Becker ${ }^{38}$, Morgulis ${ }^{29)}$, Gunther

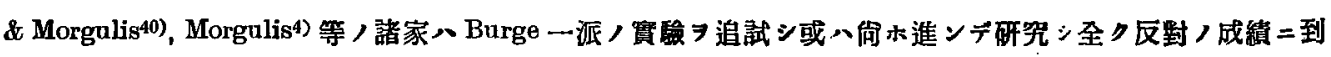

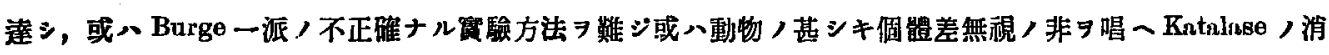
長八新陳代謝ト何等，關係ナシト諭断ス. Batelli u. Stern E(1905) 八各種動物ノ組織及ビ血液ニ於ヶル 


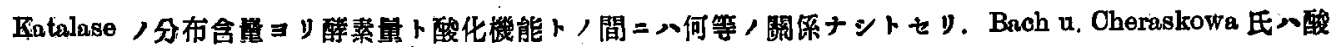

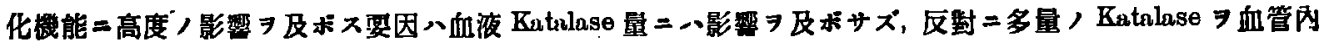

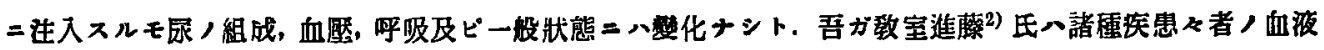

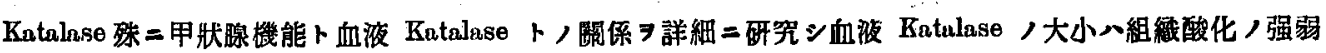

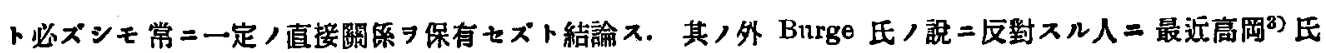

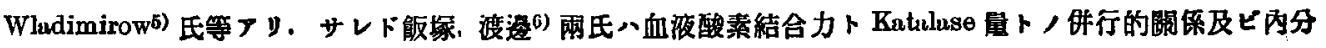

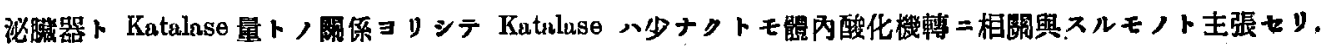

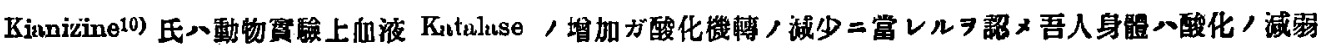

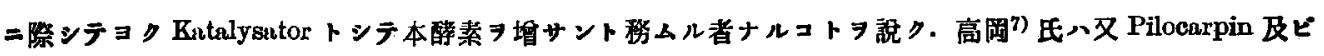

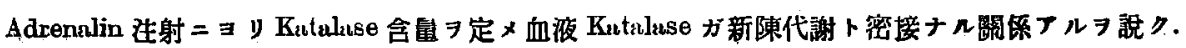

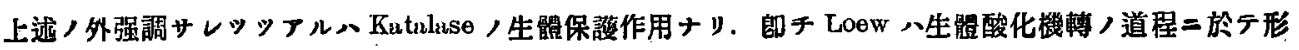

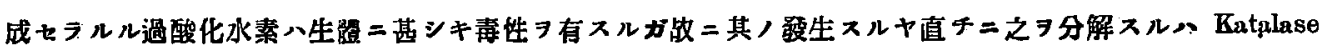

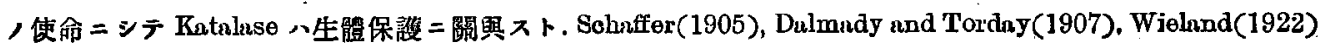

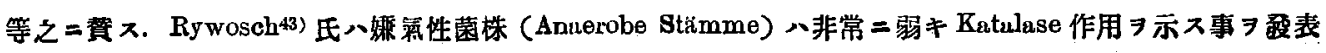

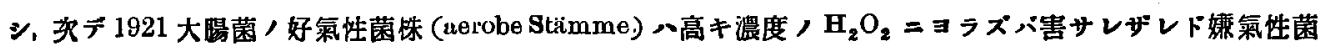

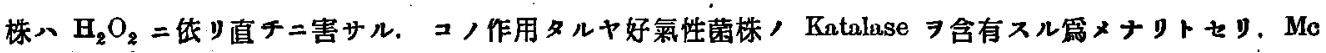

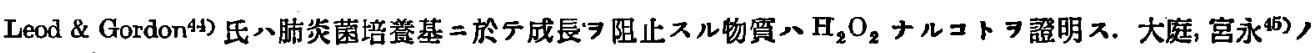

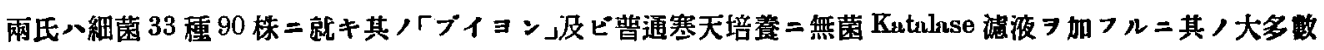

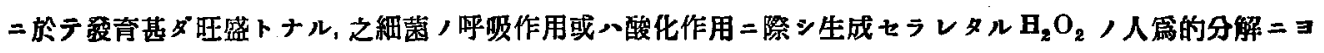

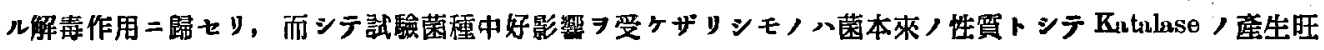
盛ナル淋菌. 孁菌, 䖝光菌等ナリキ.

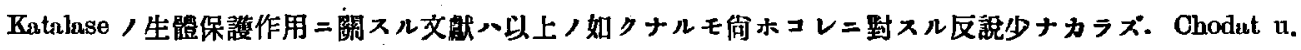

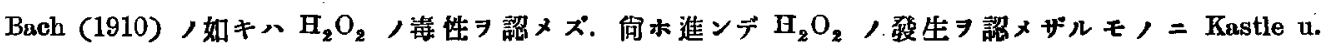

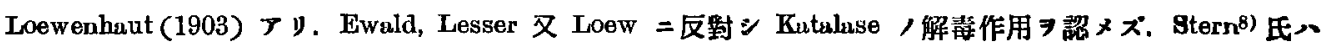

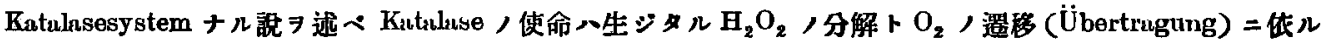
酸化機轉, 促進二エリトス.

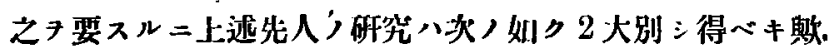

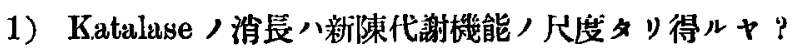

2) Katalase 八生體保䕶作用有スルヤ?

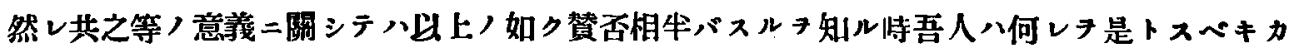

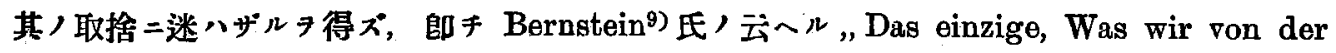
Katalase sicher wissen, ist deren Fähigkeit, $\mathrm{H}_{2} \mathrm{O}_{2}$ in vitro $\mathrm{zu}$ spalten.“ コノ一事ノi 以テ满是スベキニハ非ザルカ. 斯ルガ战二淮ンデ Katalase，生理的意義习探求セント欲スル

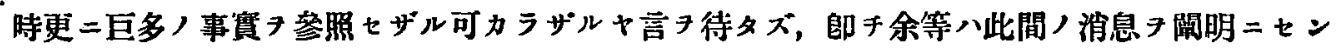




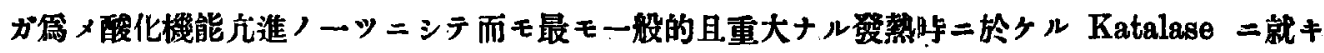
䂧索スル處フリタレバ以下其ノ詳細タ報告セントス。

\section{第 2 章實驗材料及ビ宽醶方法}

\section{(A) 血液 Katalase 實驗方法}

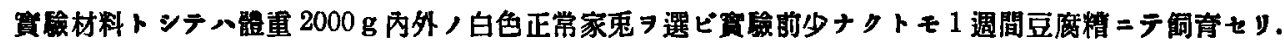

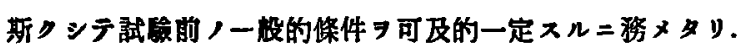

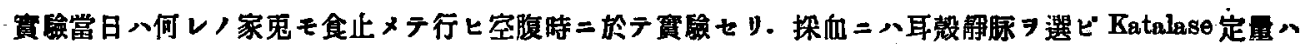

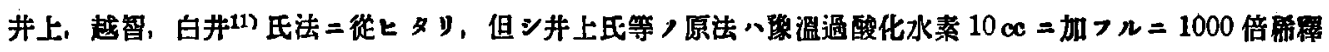

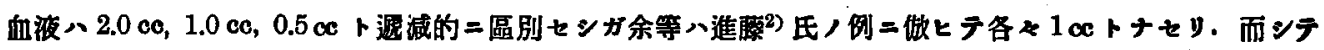

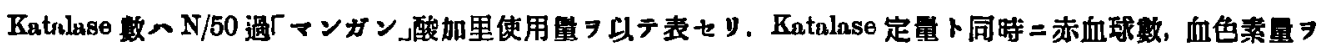

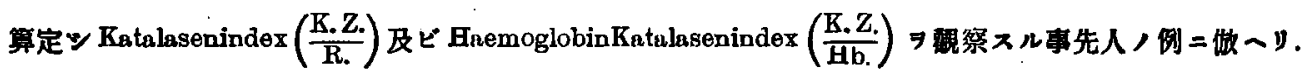

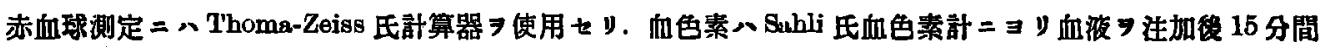

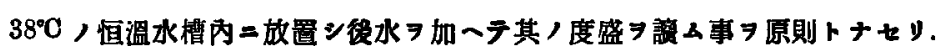

\section{(B) 膆器 Katalase 賽驗方法}

赛驗家鬼

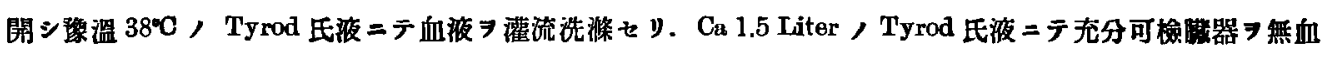

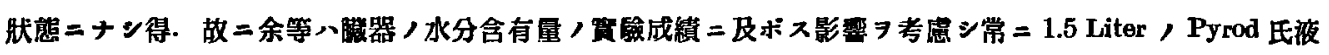
ニテ灌流スル事トナセり.

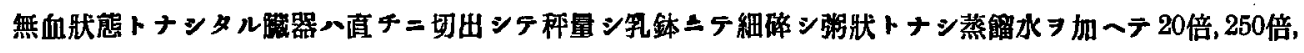

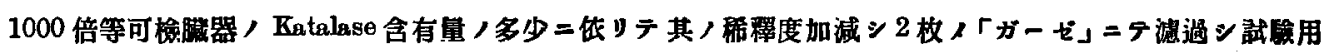

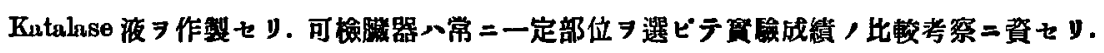

\section{(C) 發熱汸 法}

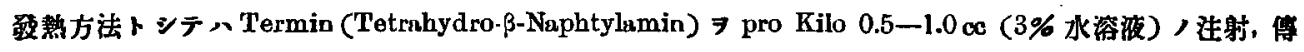

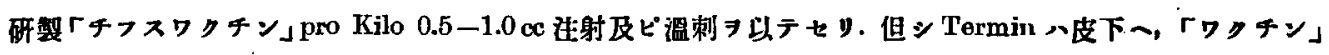
、耳静脉一䂑 $\times$ 徐

\section{第 3 章 宽 驗 成 績}

第 1 節 發热卜血液 Katalase

第 1 項 對 照 試 驗

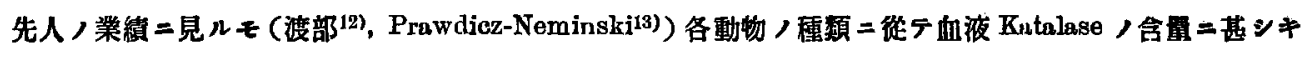

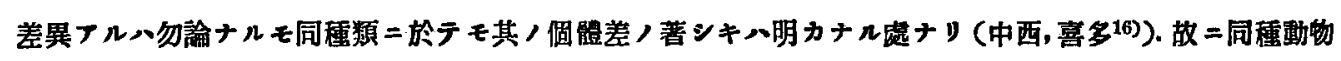

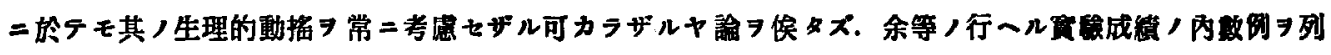
翼スレバ夷/如ッ. 
第 1 表 正常家鬼直液 Katalase

\begin{tabular}{|c|c|c|c|c|c|c|c|}
\hline 温 & K. $\mathbf{Z}$. & $\mathbf{R}$. & Hb. & K. I. & H. K. I. & 備 & 考 \\
\hline $\begin{array}{l}38.8 \\
38.5 \\
38.6\end{array}$ & $\begin{array}{r}10.5 \\
10.9 \\
11.0\end{array}$ & $\begin{array}{l}612 \\
632 \\
624\end{array}$ & $\begin{array}{l}93 \\
95 \\
93\end{array}$ & $\begin{array}{l}0.017 \\
0.017 \\
0.018\end{array}$ & $\begin{array}{l}0.113 \\
0.116 \\
0.118\end{array}$ & $\begin{array}{c}\text { 骫重 } \\
\text { 白 }\end{array}$ & $\begin{array}{c}2030 \mathrm{~g} \\
\text { 우 }\end{array}$ \\
\hline $\begin{array}{l}38.0 \\
38.3 \\
38.2\end{array}$ & $\begin{array}{l}10.9 \\
11.0 \\
10.7\end{array}$ & $\begin{array}{l}635 \\
650 \\
548\end{array}$ & $\begin{array}{l}87 \\
89 \\
85\end{array}$ & $\begin{array}{l}0.017 \\
0.017 \\
0.020\end{array}$ & $\begin{array}{l}0.124 \\
0.124 \\
0.126\end{array}$ & $\begin{array}{c}\text { 體重 } \\
\text { 白 }\end{array}$ & $\begin{array}{c}2000 \mathrm{~g} \\
\delta\end{array}$ \\
\hline $\begin{array}{l}38.8 \\
38.3 \\
37.9\end{array}$ & $\begin{array}{l}11.3 \\
11.0 \\
10.7\end{array}$ & $\begin{array}{l}715 \\
676 \\
684\end{array}$ & $\begin{array}{l}94 \\
84 \\
86\end{array}$ & $\begin{array}{l}0.016 \\
0.016 \\
0.016\end{array}$ & $\begin{array}{l}0.120 \\
0.131 \\
0.124\end{array}$ & $\begin{array}{c}\text { 䱏重 } \\
\text { 白 }\end{array}$ & $\begin{array}{c}2200 \mathrm{~g} \\
\mathrm{~s}\end{array}$ \\
\hline $\begin{array}{l}39.0 \\
38.6 \\
38.3\end{array}$ & $\begin{array}{l}8,6 \\
8.7 \\
8.9\end{array}$ & $\begin{array}{l}660 \\
652 \\
630\end{array}$ & $\begin{array}{l}80 \\
83 \\
79\end{array}$ & $\begin{array}{l}0.013 \\
0.013 \\
0.014\end{array}$ & $\begin{array}{l}0.108 \\
0.105 \\
0.112\end{array}$ & $\begin{array}{c}\text { 曧重 } \\
\text { 白 }\end{array}$ & $\begin{array}{c}1850 \mathrm{~g} \\
\quad \text { ㅇ }\end{array}$ \\
\hline $\begin{array}{l}38.2 \\
38.0 \\
38.0\end{array}$ & $\begin{array}{r}11.3 \\
11.0 \\
11.2\end{array}$ & $\begin{array}{l}752 \\
748 \\
751\end{array}$ & $\begin{array}{l}93 \\
93 \\
93\end{array}$ & $\begin{array}{l}0.015 \\
0.015 \\
0.015\end{array}$ & $\begin{array}{l}0.122 \\
0.118 \\
0.120\end{array}$ & $\begin{array}{c}\text { 體重 } \\
\text { 白 }\end{array}$ & $\begin{array}{c}1830 \mathrm{~g} \\
\delta\end{array}$ \\
\hline $\begin{array}{l}38.5 \\
38.5 \\
38.4\end{array}$ & $\begin{array}{r}14.9 \\
15.0 \\
14.8\end{array}$ & $\begin{array}{l}596 \\
599 \\
578\end{array}$ & $\begin{array}{l}88 \\
89 \\
88\end{array}$ & $\begin{array}{l}0.025 \\
0.025 \\
0.025\end{array}$ & $\begin{array}{l}0.169 \\
0.168 \\
0.170\end{array}$ & 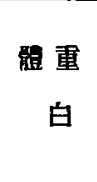 & $\begin{array}{c}2000 \mathrm{~g} \\
\text { 우 }\end{array}$ \\
\hline
\end{tabular}

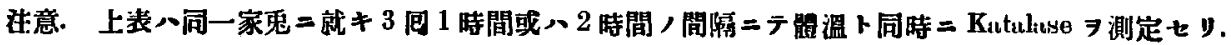
上表二用ヒシ略字次ノ如シ，以下之二海ズ。
K. Z. (Katulase 數)
Hb. (血色素)
R. (赤血䇝)
K. J. (Kutuluse 佋旼)
H. K. I. (血色素 Katralase 俰數)

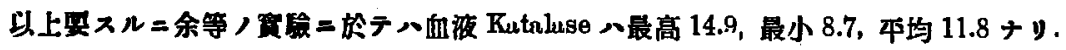

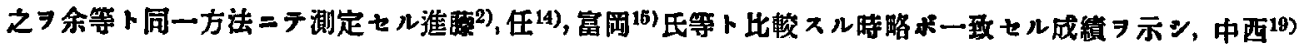

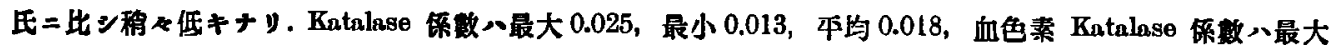
0.187 ，最小 0.108 ，平勾 0.141 ナり。 
第 2 項 發熱時算 驗

第 2 表 Termin 注射家患血液 Katalase

\begin{tabular}{|c|c|c|c|c|c|c|c|}
\hline 經過時間 & 體 ${ }^{\circ} \mathrm{C}$ & K. Z. & R. & Hb. & K. . & Н. K. I. & 考 \\
\hline 注 射前 & 39.0 & 14.4 & 684 & 84 & 0.021 & 0.171 & \multirow{4}{*}{$\begin{array}{c}\text { I } \\
\text { 體重 } 2300 \mathrm{~g} \\
\text { 白 } \mathrm{g}\end{array}$} \\
\hline 後 30 分 & 40.0 & 14.9 & 744 & 87 & 0.020 & 0.171 & \\
\hline 後 1時間 & 40.9 & 16.0 & 764 & 93 & 0.021 & 0.170 . & \\
\hline 後 2 時間 & 42.0 以上 & 16.5 & 785 & 98 & 0.021 & 0.171 & \\
\hline 注 射 前 & 39.0 & 11.4 & 659 & 92 & 0.017 & 0.124 & II \\
\hline 復 30 分 & 40.5 & 11.9 & 728 & 94 & 0.016 & 0.127 & \multirow{3}{*}{ 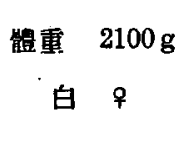 } \\
\hline 唚 1時間 & 40.7 & 12.3 & 768 & 98 & 0.016 & 0.125 & \\
\hline 後 2 時間 & 42.0 以上 & 12.6 & 827 & 101 & 0.015 & 0.124 & \\
\hline 注 射 前 & 39.5 & 10.5 & 596 & 80 & 0.017 & 0.131 & III \\
\hline 後 30 分 & 41.1 & 12.6 & 706 & 93 & 0.018 & 0.135 & \multirow{3}{*}{$\begin{array}{c}\text { 咀重 } 2200 \mathrm{~g} \\
\text { 白 } 9\end{array}$} \\
\hline 徢 1時間 & 41.7 & 13,3 & 782 & 98 & 0.017 & 0.136 & \\
\hline 後 2時間 & 42.0 上上 & 14.0 & 802 & 101 & 0.017 & 0.135 & \\
\hline
\end{tabular}

第 1 圖 （第 2 表附圖）
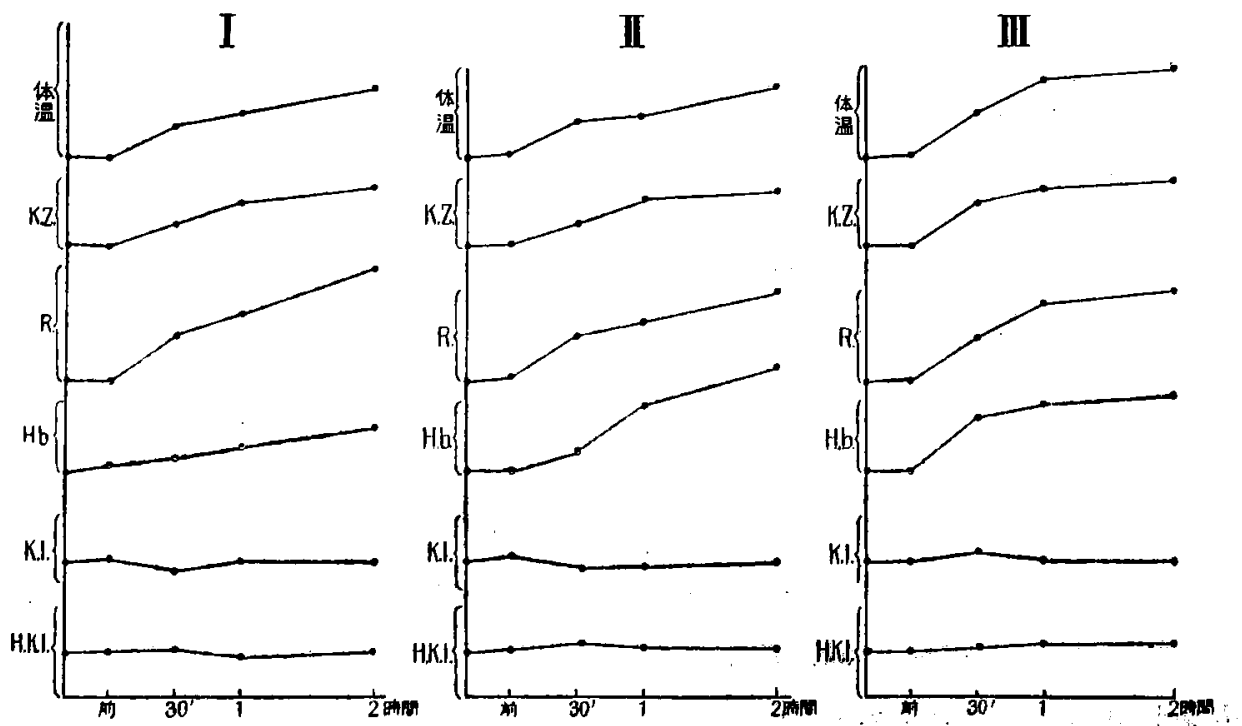
第 3 表 「キフスワクチン」注射家鬼血液 Katalase

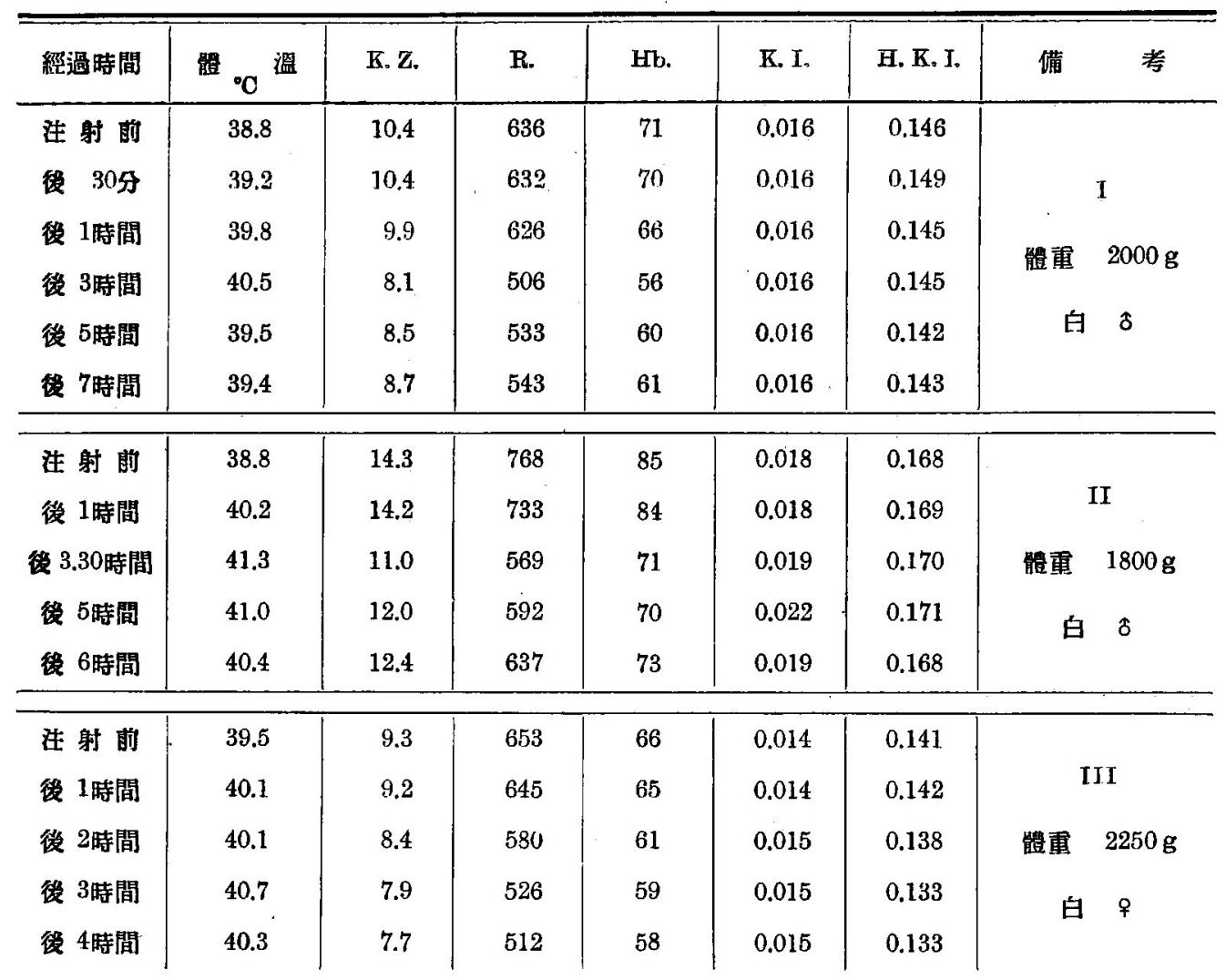

\section{第 2 圖（第 3 表附圖）}

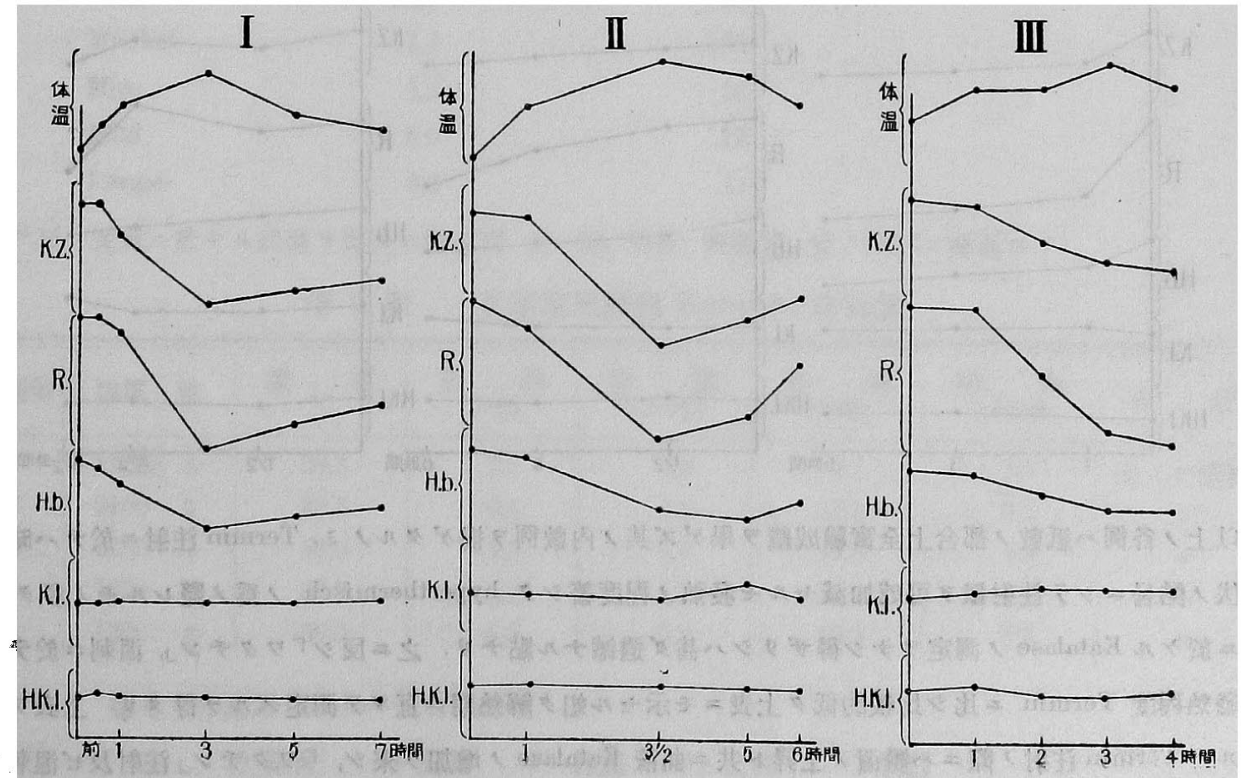


第 4 表 溫刺家鬼血液 Katalase

\begin{tabular}{|c|c|c|c|c|c|c|c|}
\hline 經過時間 & 體 & K. Z. & $\mathbf{R}$ & Hb. & K. I. & H. K. I. & 考 \\
\hline 溫 剌 郋 & 39.3 & 10.0 & 592 & 73 & 0.017 & 0.137 & \multirow{4}{*}{$\begin{array}{c}\text { 體重 } 1800 \mathrm{~g} \\
\text { 白 } \&\end{array}$} \\
\hline 復 1 時間 & 40.3 & 9.3 & 519 & 67 & 0.018 & 0.139 & \\
\hline 後 3 時間 & 40.4 & 9.2 & 510 & 66 & 0.018 & 0.140 & \\
\hline 徙 5 時間 & 40.4 & 9.0 & 500 & 63 & 0.018 & 0.143 & \\
\hline 温 刺 刖 & 39.5 & 9.3 & 652 & 76 & 0.014 & 0.122 & \multirow{2}{*}{ II } \\
\hline 後 1.30 時間 & 40.3 & 9.2 & 648 & 75 & 0.014 & 0.123 & \\
\hline 骁 4 時間 & 40.1 & 8.9 & 630 & 74 & 0.014 & 0.120 & \multirow{2}{*}{ 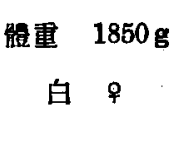 } \\
\hline 後 6 時間 & 39.5 & 8.7 & 588 & 70 & 0.015 & 0.124 & \\
\hline 溫 刺 前 & 38.7 & 14.5 & 646 & 85 & 0.023 & 0.171 & III \\
\hline 後 1.30 時間 & 40.3 & 14.1 & 635 & 83 & 0.022 & 0.170 & \multirow{3}{*}{$\begin{array}{c}\text { 白 } 9 \\
\text { 自 }\end{array}$} \\
\hline 後 3.30時間 & 40.9 & 14.4 & 655 & 81 & 0.022 & 0.178 & \\
\hline 後 4.30時間 & 41.1 & 13.9 & 595 & 80 & 0.025 & 0.174 & \\
\hline
\end{tabular}

第 3 圆（第 4 表 附圆）

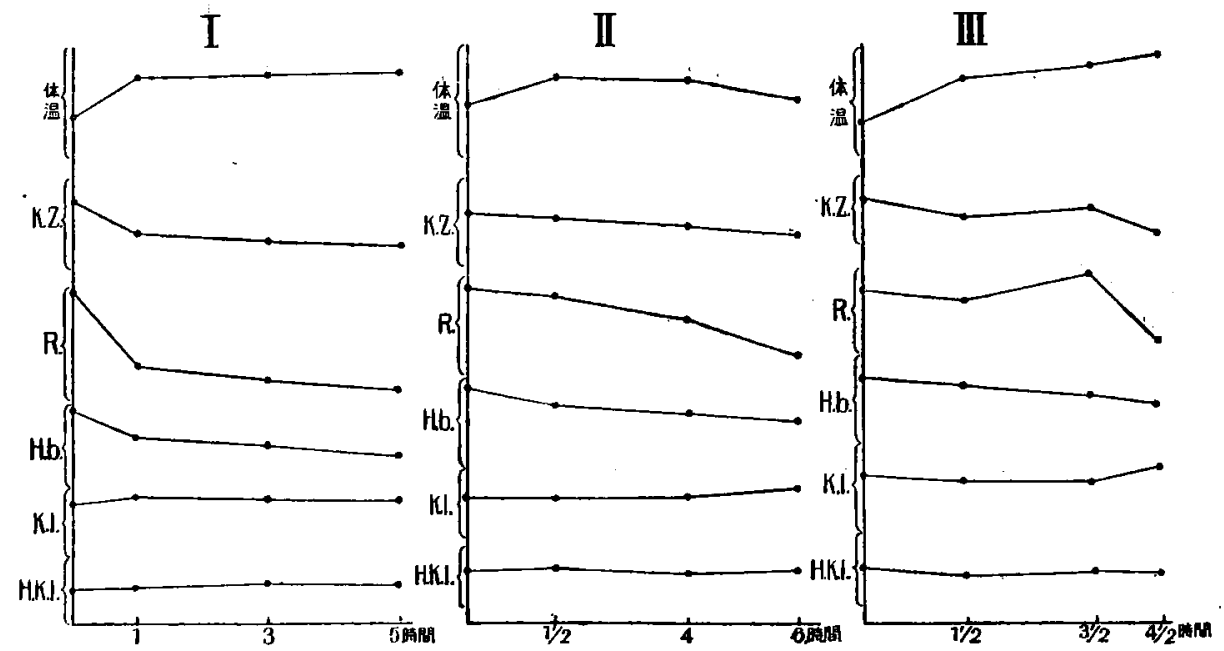

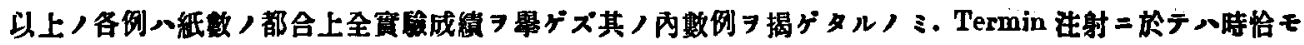

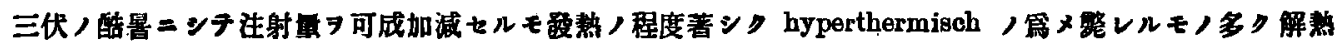

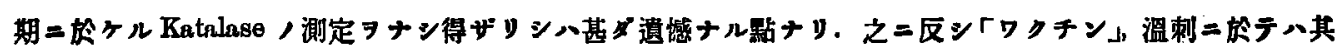

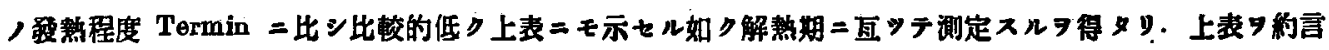

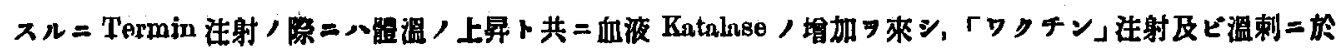


テン發熱ト平行シテ血液 Katalase，隇少

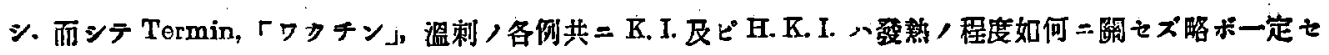
$\varkappa \Rightarrow$ 見々y.

\section{第 2 節 發熱ト臟器 Katalase}

第 1 項 照試 驜

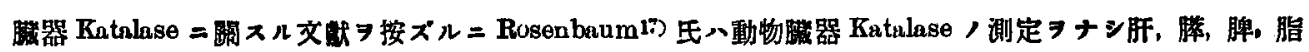

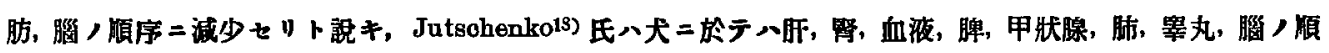

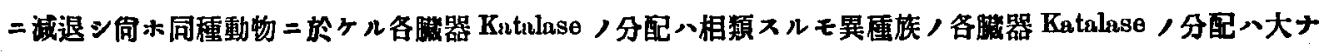
ル差アリト.

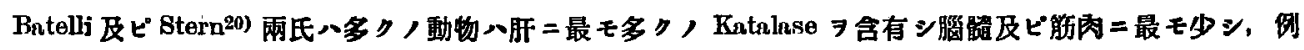

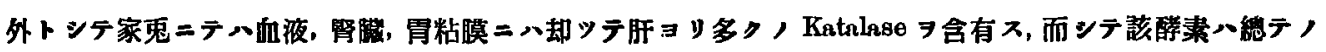

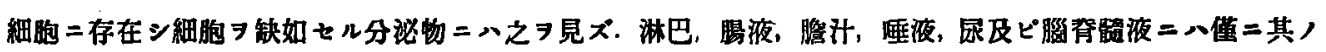
痕跡

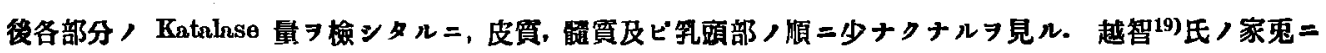
ヨル䑏器 Katalase，成績 7 見ル $=\operatorname{Blut}(100 \%)$, Niere (77\%), Leber (72.5\%), Nebenniere (25.0\%), Knochenmerk (3.9\%), Thymus (2.4\%), Muskel (1.2\%), Hoden (1.0\%), Gehirn (微量) ノ順ナリ. Stern9)

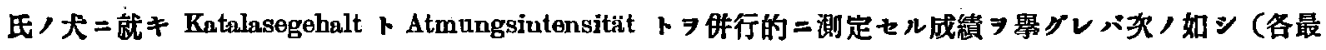
大量 $\ni 100$ ニテ表ス).

$\begin{array}{lcc}\text { Gewebe } & \text { Katralnsegehalt } & \text { Atmungsintensitut } \\ \text { Leber } & 100.0 & 84 \\ \text { Niere } & 93.0 & 95 \\ \text { Muskel } & 1.4 & 100 \\ \text { Hïrn } & 1.1 & 78 \\ \text { Milz } & 5.0 & 12 \\ \text { Lunge } & 8.3 & 13\end{array}$

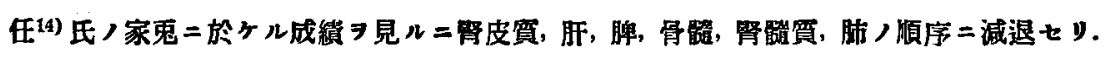

第 5 表 正常家鬼哭器 Katalase 含有量

\begin{tabular}{|c|c|c|c|c|c|c|c|}
\hline 家鬼穞䞊 & 體重 性 & 體 ${ }^{\text {c }}$ 溫 & 的 20 倍 & 肝 & $\begin{array}{c}\text { 脾 } \\
250 \text { 倍 }\end{array}$ & $\begin{array}{c}\text { 副 } \\
1000 \text { 倍 }\end{array}$ & 朔 \\
\hline Nr. 1 & $1850 \mathrm{~g}$ & 39.8 & 7.5 & 2.6 & 8.7 & 3.7 & 極メテ微量 \\
\hline 2 & 2100 & 39.5 & 6.5 & 4.9 & 16.8 & 5.3 & ? \\
\hline 3 & 2250 & 39.0 & 3.5 & 4.0 & 14.0 & 4.5 & $\Rightarrow$ \\
\hline 4 & 1830 & 38.7 & 3.2 & 6.5 & 10.1 & 7.0 & . \\
\hline 5 & 1900 & 39.5 & 5.0 & 5.2 & 10.3 & 7.7 & , \\
\hline
\end{tabular}

借考 各㗊 Katalase 含有墨比較
1) 副艮
2) 肝陪
3) 脾䑏
4) 符肉
5) 腦路 


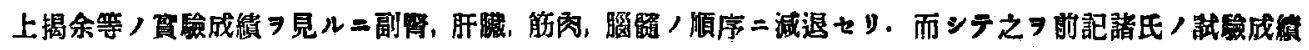

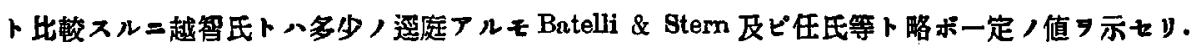

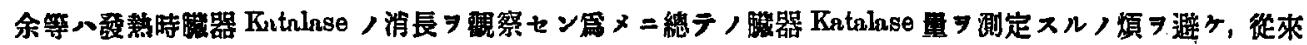

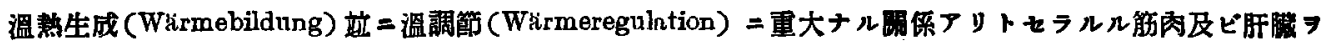

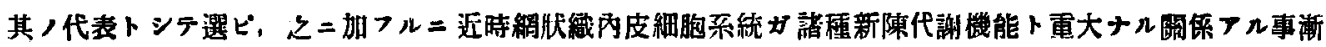

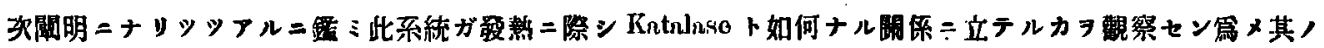
代表トシテ脾䁤 $、$ 選へリリ。

第 6 表 正常家鬼臟器 Katalase 含有量

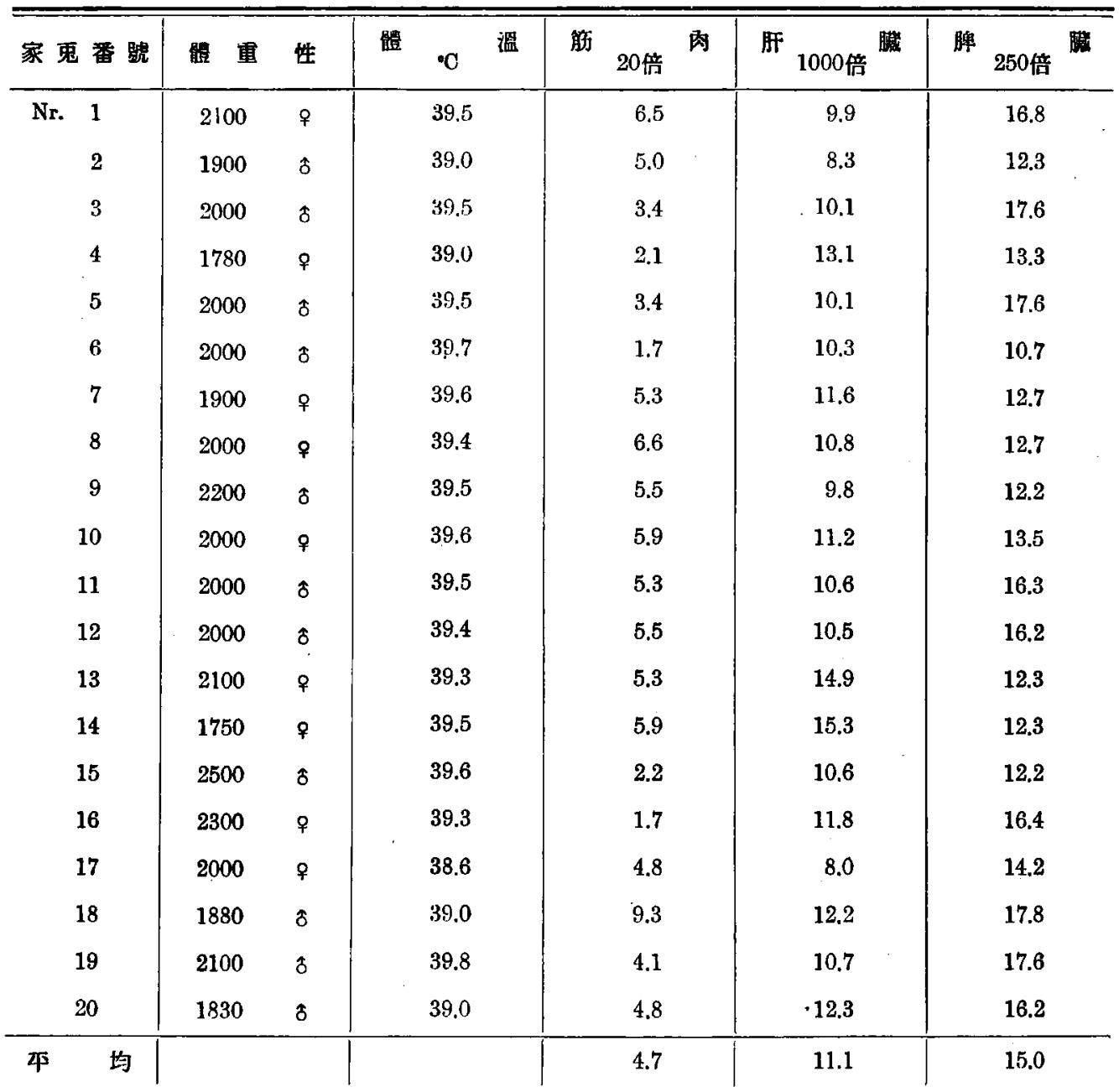

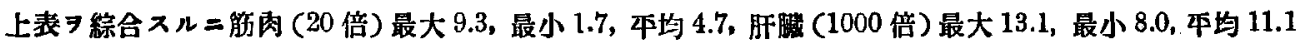

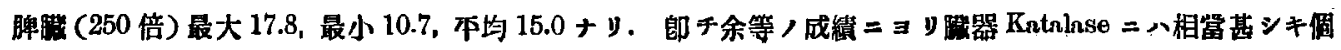
顝击フルョ知ルナリ。 
第 2 項 發熱時察駰

第 7 表 發熱卜鈢誉 Kataluse 量，變化

\begin{tabular}{|c|c|c|c|c|c|c|c|c|}
\hline \multicolumn{2}{|c|}{ 家鬼番憱 } & 黢熱方法 & 體溫上昇昇度 & 時 & 間 & 筋 20 倍 & ${ }_{1000 \text { 倍 }}$ & ${ }_{250 \text { 倍 }}$ \\
\hline \multirow{13}{*}{ Nr. } & 1 & \multirow[b]{3}{*}{7} & $39.1 \rightarrow 41.3$ & \multicolumn{2}{|c|}{ 任射後 3 時間 } & 3.7 & 9.4 & 19.0 \\
\hline & 2 & & $39.2 \rightarrow 40.5$ & & $41 / 2$ & 2.5 & 10.5 & 17.6 \\
\hline & 3 & & $39.0 \rightarrow 40.9$ & \multicolumn{2}{|r|}{$5.1 / 2$} & 1.8 & 13.1 & 16.7 \\
\hline & 4 & \multirow{10}{*}{$\begin{array}{l}7 \\
\text { z } \\
\square \\
y \\
y \\
\text { ¿ } \\
\text { 溇 } \\
\text { 射 }\end{array}$} & $38.7 \rightarrow 40.5$ & \multicolumn{2}{|r|}{4} & 5.1 & 10.2 & 13.4 \\
\hline & 5 & & $39.7 \rightarrow 41.4$ & \multicolumn{2}{|r|}{3} & 8.5 & 12.2 & 20.9 \\
\hline & 6 & & $39.6 \rightarrow 41.2$ & \multicolumn{2}{|r|}{2} & 2.4 & 9.4 & 13.9 \\
\hline & 7 & & $39.3 \rightarrow 41.3$ & \multicolumn{2}{|r|}{$31 / 2$} & 3.0 & 12.7 & 13.5 \\
\hline & 8 & & $39.4 \rightarrow 41.5$ & \multicolumn{2}{|r|}{$21 / 2$} & 1.9 & 8.9 & 11.1 \\
\hline & 9 & & $39.8 \rightarrow 41.2$ & \multicolumn{2}{|r|}{$21 / 2$} & 7.0 & 12.5 & 19.7 \\
\hline & 10 & & $39.9 \rightarrow 41.9$ & \multicolumn{2}{|r|}{$11 / 2$} & 4.4 & 10.0 & 12.9 \\
\hline & 11 & & $38.9 \rightarrow 40.0$ & \multicolumn{2}{|r|}{$21 / 2$} & 5.1 & 12.1 & 14.6 \\
\hline & 12 & & $39.3 \rightarrow 40.7$ & \multicolumn{2}{|r|}{2} & 6.2 & 10.9 & 18.8 \\
\hline & 13 & & $38.7 \rightarrow 40.2$ & \multicolumn{2}{|r|}{2} & 2.7 & 12.2 & 15.2 \\
\hline \multicolumn{2}{|l|}{4} & & & & & 3.8 & 11.1 & 15.9 \\
\hline \multirow[t]{9}{*}{$\mathrm{Nr}}$. & 1 & \multirow{3}{*}{$\bar{\tau}$} & $39.9 \rightarrow 42.8$ & 注射後 & \multirow{2}{*}{ 5/6時間 } & 7.2 & 9.4 & 15.9 \\
\hline & 2 & & $40.0 \rightarrow 42.9$ & & & 3.2 & 13.1 & 13.6 \\
\hline & 3 & & $38.9 \rightarrow 43.0$ & \multicolumn{2}{|c|}{1} & 4.9 & 16.3 & 16.5 \\
\hline & 4 & \multirow{2}{*}{$n$} & $39.9 \rightarrow 43.0$ & \multicolumn{2}{|c|}{1} & 3.0 & 12.3 & 17.9 \\
\hline & 5 & & $39.7 \rightarrow 43.0$ & \multicolumn{2}{|c|}{1} & 2.8 & 9.3 & 11.3 \\
\hline & 6 & $\stackrel{2}{L}$ & $39.9 \rightarrow 43.5$ & \multicolumn{2}{|c|}{$11 / 2$} & 8.6 & 9.4 & 15.1 \\
\hline & 7 & 注 & $39.5 \rightarrow 41.0$ & \multicolumn{2}{|c|}{2} & 6.3 & 11.8 & 16.9 \\
\hline & 8 & 射 & $39.5 \rightarrow 43.0$ & 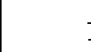 & 1 & 2.9 & 9.3 & 14.7 \\
\hline & 9 & & $39.2 \rightarrow 43.0$ & 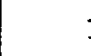 & 1 & 2.3 & 12.7 & 14.6 \\
\hline 平 & 均 & & & & & 4.6 & 11.5 & 15.2 \\
\hline $\mathbf{N r}$ & 1 & & $38.7 \rightarrow 40.8$ & 溫刺徐 & 3 時間 & 4.5 & 15.0 & 16.9 \\
\hline & 2 & 㴓 & $39.1 \rightarrow 40.9$ & & 6 & 1.3 & 16.2 & 21.2 \\
\hline & 3 & 傦 & $38.8 \rightarrow 40.8$ & & 6 & 8.7 & 12.1 & 12.4 \\
\hline & 4 & & $39.1 \rightarrow 40.4$ & & 7 & 4.7 & 12.4 & 15.9 \\
\hline & 5 & & $39.5 \rightarrow 40.8$ & & 3 & 5.9 & 12.3 & 17.3 \\
\hline & 6 & 刺 & $39.5 \rightarrow 40.7$ & & $41 / 2$ & 4.7 & 14.4 & 15.6 \\
\hline & 7 & & $39.0 \rightarrow 41.3$ & & 6 & 8.6 & 14.0 & 18.5 \\
\hline 4 & 均 & & & & & 4.63 & 13.8 & 16.8 \\
\hline 正常 & 平均 & & & & & 4.7 & 11.1 & 15.0 \\
\hline
\end{tabular}




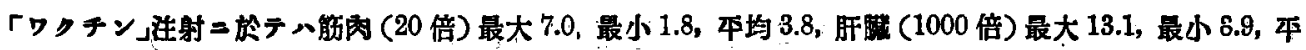
均 11.1，脾践 (250 倍)，最大 $20.9 ，$ 最小 $11.1 ，$ 本均 15.9 ナリ，

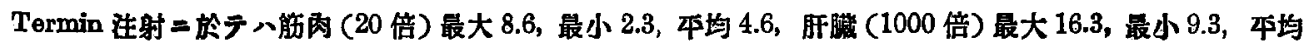

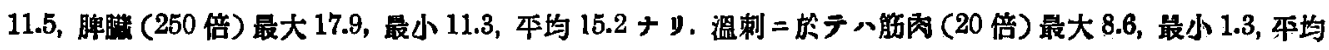
4.6 , 肝縢 (1000 倍) 最大 16.2 ，最小 12.1 ，平均 13.8 , 脾滕 (250 倍) 最大 21.2 , 最小 12.4 , 平均 16.8 ナリ.「口

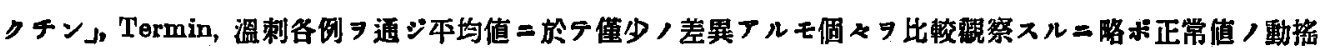

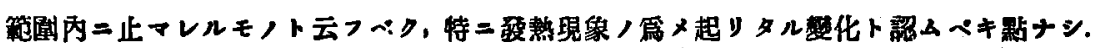

\section{第 4 草 總括及ヒ考察}

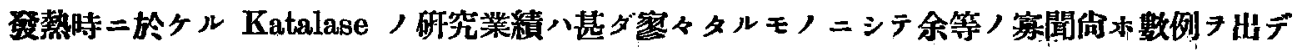

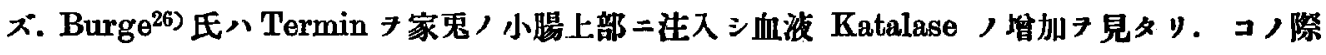

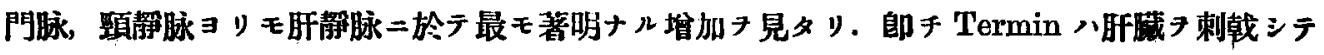
Katalase ノ產生キ促スナリ. Adrenalin, Coffein, Sodiumchlorid, getrocknete Schilddrüse,

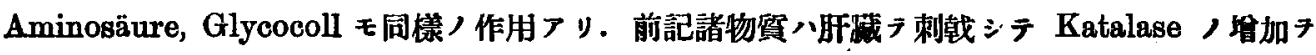

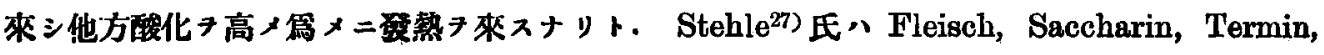
Alamin, Glycocoll etc. 7 與へテ血液 Katalase ノ消長 $\ni$ 檢 シ Katalase ト酸化トノ間二直

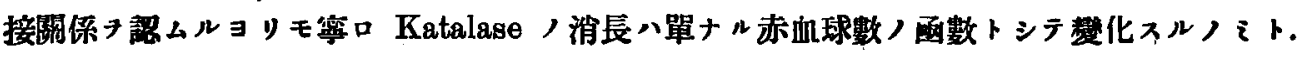

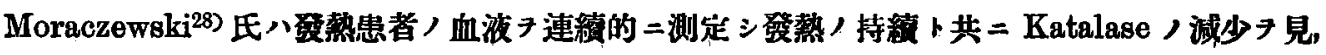

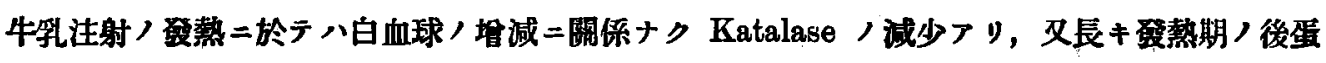

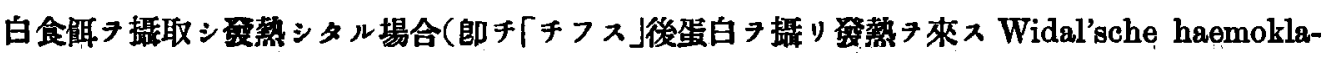
stische Shock =比スベキ狀態)ト肝辕機能不全 (Leberinsuffizienz)），後 Milchgenuss 二テ

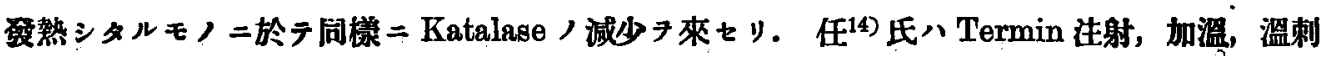

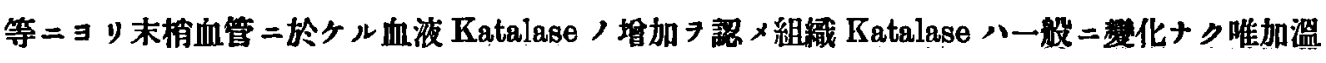

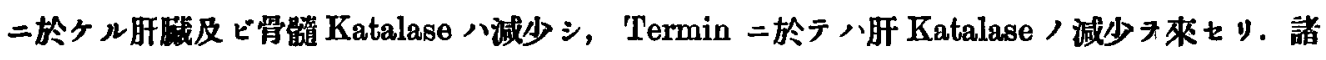
種發熱疾患時二於々ル血液 Katalase，消長ハ程々䂥罙サレフリ而シテコノ際疾患/種類二依

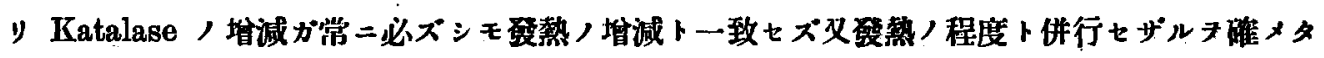

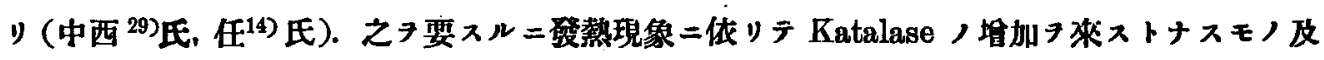
ビ誡少フ來ストナスモノノ全ク相反スル成績二到澾スルナリ。

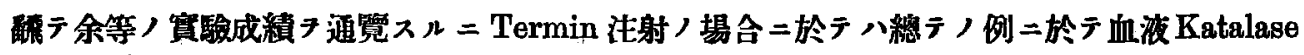
及ビ血色素, 赤血球ノ管加フ來ス. 其八程度ハ凡ソ發熱，程度ト本行スルモノノ如クコノ際前

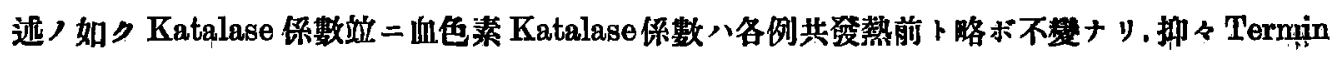

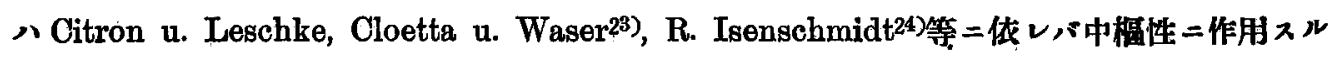

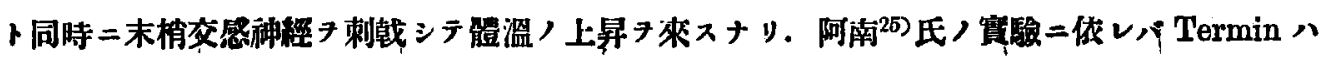




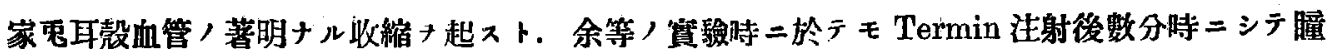

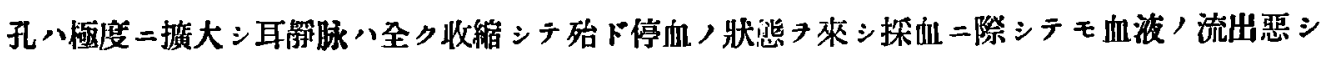

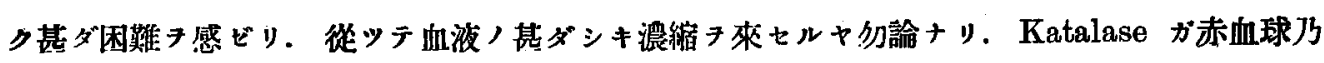
至血色素ノ多少ト相本行スルハ多クノ人ニヨy. (Jolles (1905), Loeb (1908), Becht (1919), Stchle (1919), Niesen (1921), Senter (1921), Moraczewski (1923)，進櫒 (1928)) 認メラル ル處ニシテ文余等，實驗二於テ Katalase 保數，血色素 Katalase 係數ノ略ボ不變二止ルキよテ

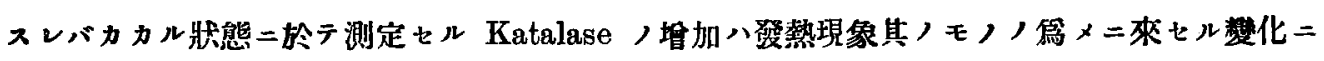

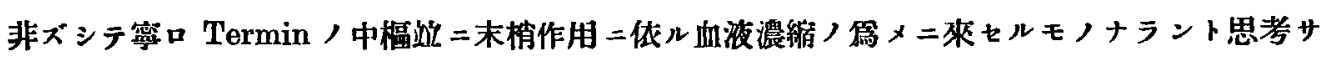

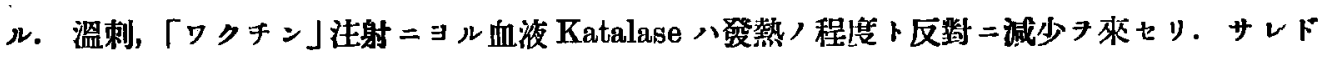

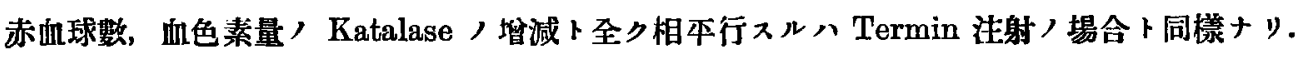

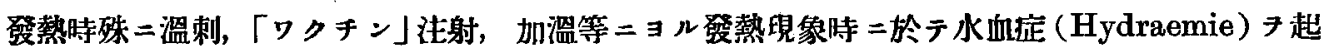

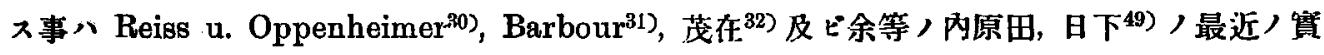
驗成績二徽スルモ明カナル事實ニシテ余等 質驗 =於テ Katalase，消長ガ赤血球數，血色素

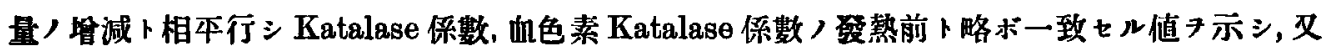

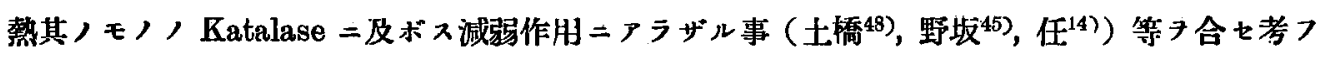
ル時 Katalase ノ減少ハ主トシテ水血症 (Hydraemie) 二因スルモノナラント思惟サルルナリ.

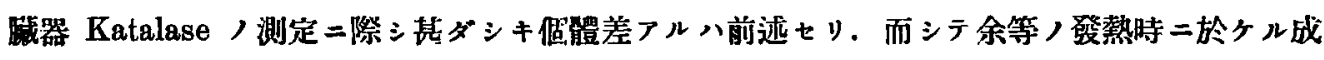

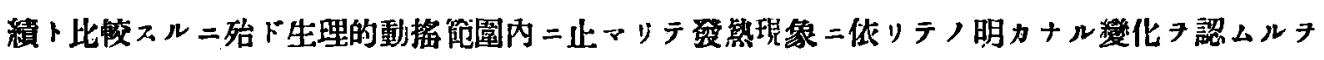

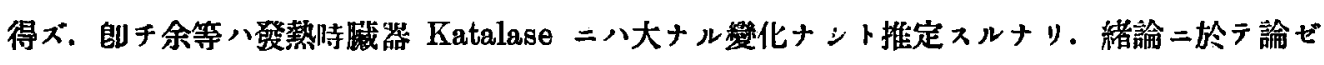

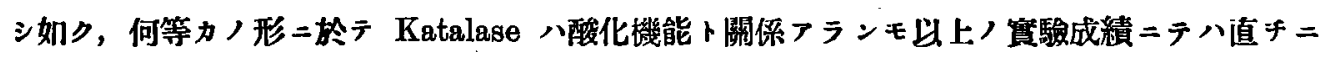

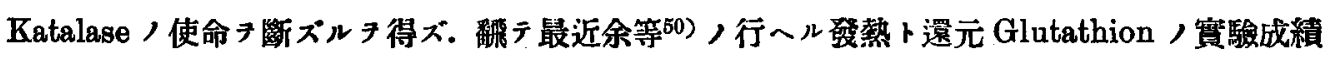
フ見ル二明カ二發熱二際シ殊二酸化機能立進セリト認メラルル肝, 肺, 筋肉等二還元Glutathion

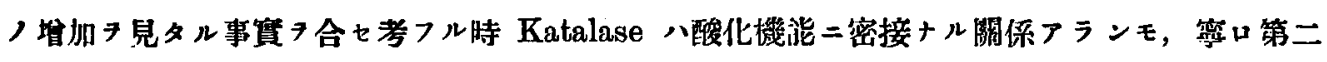
次的二於テデアリ，從ッテ少ナクトモKatalase，消長キ以テ組織酸化ノ大小八判定シ得ザル

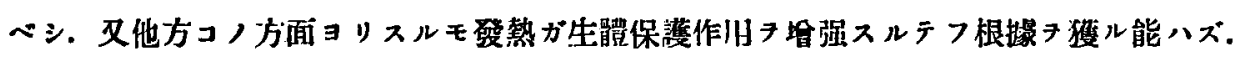

\section{第 5 章 結 論}

1）正嫦家鬼血液 Katalase 八最大 14.9 , 最小 8.7 , 平均 11.8 , Katalase 係數最大 0.025 , 最 小 0.013 , 平均 0.018 , 血色素 Katalase 你數最大 0.187 , 最小 0.108 , 本均 0.141 ナリ.

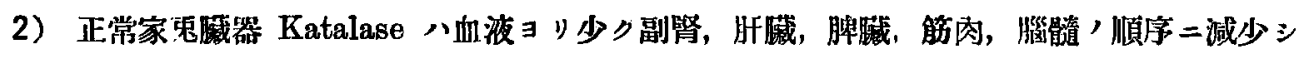
甚ダシキ個體差アルフ諰ム。

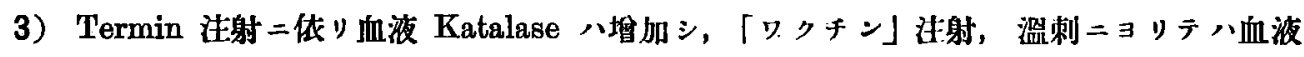

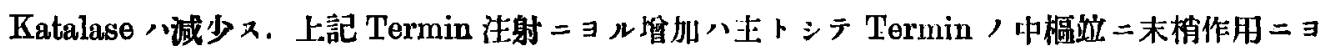


ル血液濃縮ノ雼メノ如ク,「ワクチン」注射, 溫制ニヨル娍少ハ重二水血症 $($ Hydraemí $)=$ 原 因スルモノナラン幗.

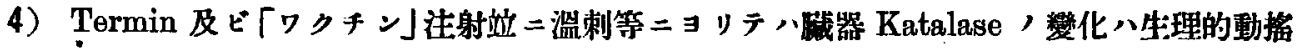
範圍キ出デザルモノノ如シ。

上上ノ實驗成績 $=ヨ$ レ゙發熱時二於ヶル血液及ビ裁器 Katalase ニ八大ナル變化ナク，從ッ

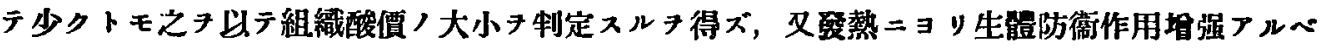
キチ肯定スル能ハズ。

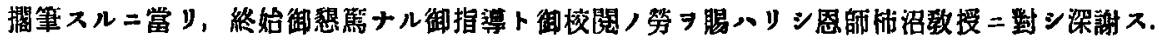

(6. 2. 27. 受樆)

\section{文獻}

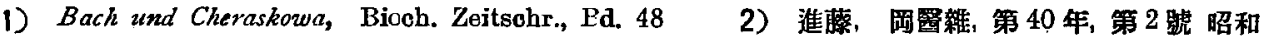

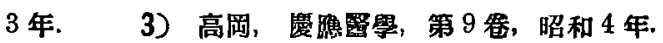

4) Morgutis, Ergeb. d. Physiol., 23, 1924. 5) Wladimirow, Biooh. Zeitsohr., Bd. 192, 1928.

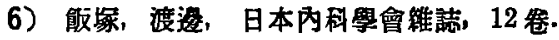

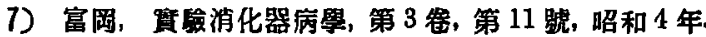

8) Stern, Bioch. Zeitsohr., Bd. 182, 1927.

9) Bernstein, Bioch. Zeitschr., Bd. 179, $1926 . \quad 10$ j Kianizine, J. de physiol. et de path. géne., Tome 21, 1923. 11) 并上, 越智, 白井, 東京㗨學會雜誌, 第 34 坴, 大正 9 年. 12) 渡部, 日本微 生物學會雓誌, 18 怣, 大正 13 年. 13） Prawdicz-Neminski，Bioch. Zeitschr., Bd. 192, 1928. 14）任,

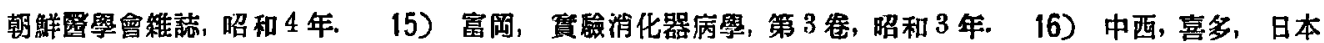

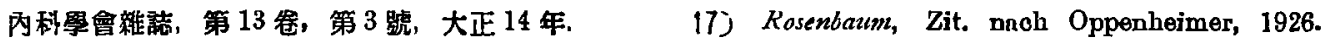
18） Juschenko, Zit. nuch Oppenheimer, 1926. 19）越智, 北海道堅學維誌, 昭和 4 年. 20）Batelli und Stern, Zit. naoh Oppenheimer. 21) Morgulis and Levine, J. of b. chem., 41, 1920. 22) Citron u. Leschke, Biuch. Zeitschr., Bd. 14, 1920. 23) Cloetta u. Waser, Ebenda, Bd. 73, 1920. 24) $R$.

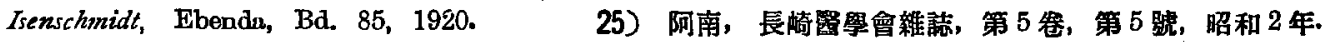
26) Burge, The j. of pharm. and thernp., Vol. 14, 1920. 27) Stehle, The j. of biol. chem., Vol.

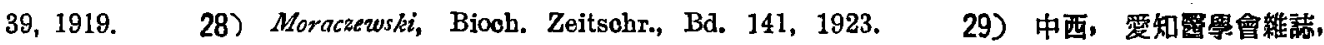
第 30 爸, 大正 12 年. 30) Reiss u. Oppenheimer, Ergeb. d. inn. Med. v. Kinderbeilk., Bd. 10, 1913.

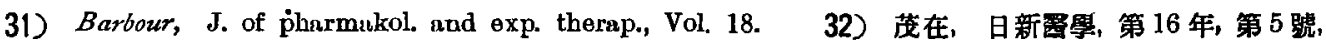
33) Loeb und Muctzer, Bioch. Zeitschr., Bd. 13, 1908. 34) Becht, Amer. j. of physiol., 48, 1919. 35) Winternilz u. Pratt, J. of exp. Med., 12, 1910. 36) Burge w. E., Burge e. L., Kennedy Neil and Ashman, Amer. J. of physiol., 34, 42, 43, 44, 47, 55, 56, 59, 61, 69. 37) Reimann and Bloom, J. of biol. chem., 36, 1918. 38) Reimann and Becher, Amer. j. of physiol., 50, $1919 . \quad 39$ ) Morgutis, Amer. j. of physiol., 57, $1921 . \quad$ 40) Gunther and Mtorgutis, Amer. j. of physiol., 59, 1922. 41) Rywosch, Zentralbl. Physiol., 21, 1907.4 42) Mc Leod and Gordon, Biochem. Jour., 16, 1907.

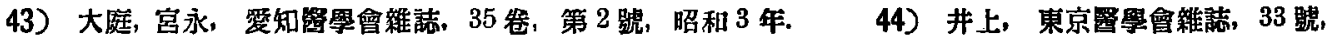
大正 8 年. 45） $K$. Nosaka, J. of Bioch., Vol. 8, 1928. 46) J. Magat, Zeitschr. f. exp. Med., Bd. 36, 1923.47$)$ Walling and Stoland, Amer. j. of physiol., 66, 1923. 48) Tsuchihashi, Bioch.

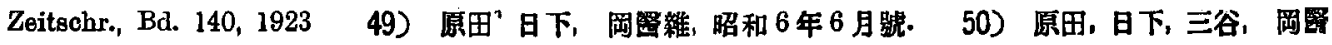
雑, 昭和 6 年 7 月號. 
Kurze Inhaltsangabe.

\title{
Fieber und Katalase.
}

\author{
Von \\ Dr. med. Murazi Kusalka, Dr. med. Yôiti Harada und \\ Dr. med. Noboru Mitani. \\ (Aus der med. Universitätsklinik von Prof. Dr. K. Kakinuma, Okayanua.)
}

Fingegnngen am 14. Februar 1931.

Über die physiologische Bedeutung der Katalase sind sich die einzelnen Autoren noch nicht einig. Aber die Ansicht, dass die Kataluse in einer bestimmten Beziehung zu dem Oxydationsvorgang im Gewebe stehe, wird von mehreren Autoren vertreten.

Bezüglich dieser Frage untersuchten wir die Blut- und Organkatalasenmenge an künstlich infolge Wärmestich, Termin- (Tetrahydro- $\beta$-Naphthylamin) und Vakzin-injektion fiebernden Kaninchen.

Wir konnten jedoch keine durch Fieber hervorgerufenen eigenartigen Veränderungen konstutieren und dürfen folglich, zum mindestens beim Fieber, auf Grund der Katalasenmenge über die Oxydationsintensität im Gewebe nicht urteilen. Auch konnen wir uns der Behauptung, dass die Schützwirkung des Organismus durch Temperaturanstieg gesteigert wird, nicht anschliessen. (Autoreferat.) 